\title{
Reflections on the old and new developmentalism
}

\author{
Reflexões sobre o velho e o novo desenvolvimentismo
}

JAN KREGEL ${ }^{1}$

RESUMO: O novo desenvolvimentismo proporciona uma visão da teoria do desenvolvimento do passado, bem como uma visão para o futuro. Esta avaliação aponta como ele incorpora as contribuições positivas de teóricos do desenvolvimento inicial preocupados com os problemas semelhantes da importância das taxas de câmbio no processo de desenvolvimento para fornecer uma versão contemporânea da teoria adaptada ao mundo do século XX e da financeirização.

PALAVRAS-CHAVE: Novo desenvolvimentismo; Taxas de câmbio; Teoria da paridade da taxa de juros.

ABSTRACT: New Developmentalism provides a view out how it incorporates the positive contributions of early development theorists concerned with to the past of development theory as well as a view to the future. This assessment points the similar problems of the importance of exchange rates in the development process to provide a contemporary version of the theory adapted to the twentieth century world of globalization and financialization . KEYWORDS: New Developmentalism; Exchange Rates; Interest Rate Parity Theory. JEL Classification: F31; O11; O14.

Development economics as an academic discipline was born in the interim between the two great wars. It was driven by two factors. The first was the breakup of the great European empires after the first war. It is evidenced in RosensteinRodan's classic 1943 analysis of the problems facing the newly created independent economies in south-eastern Europe. The problem was how to transform these once integrated economic regimes into economically viable independent economic units.

The second was the impact of the disintermediation of the global system of financial flows created by the Great Depression and the disintermediation of trade flows produced by the new political configurations and the rise to dominance of the US after the second war. The symbol of the problems caused by these geopolitical changes was the identification of the long-term tendency of decline in the

\footnotetext{
${ }^{1}$ Levy Economics Institute of Bard College. E-mail: kregel@levy.org. Submitted: 17/April/2017; Approved: 26/July/2017.
} 
terms of trade between primary commodities in the newly created economies and manufactured goods produced in developed industrial countries.

Both disruptions of existing integrated economic relations led to a description of the problems facing these new, developing economies as that of the relation between the "center" and the "periphery". This framework also suggested that the creation of viable economic units in the formerly integrated colonies would require a fuller sectoral diversification of domestic production. This was in sharp contrast to the then more traditional view that comparative advantage specialization would prove to be a sufficient driver of development. With former linkages to the industrialized center cut off, viability meant a more diversified domestic production structure.

Building a manufacturing sector thus became a focal point of the development discussions and the center piece of virtually all development theories, epitomized by Arthur Lewis' (1954) model of development with unlimited supplies of labor. Developing countries could thus be characterized as those who faced a distorted domestic structure of production resulting from political disruption redefining the economic unit or economic space, or those who faced a distorted domestic structure of production due to the dominance of the economic power of the center over the periphery.

The basic imbalances in domestic production structure thus dominated the discussion of the problem to be resolved and on the constraints on the preferred solution of expanding manufacturing that lay in the identification of the difference in market forces determining primary commodity prices and manufactured goods. It was the predominance of competitive pricing in internationally integrated markets that caused the tendency for decline in the terms of trade for developing countries a formed the basis for the external balance of payments constraint. It was supply and demand elasticities (Prebisch, 1959), and market form, and the denomination of contracts in foreign currency, which provided the barriers to a successful exploitation of comparative advantage in the export of primary products as a source of promoting an expansion in manufacturing.

This point of view is summarized by Kaldor (1963) "Sellers of primary commodities suffer from two important handicaps ... first ... primary producers are "price takers". A fall in demand for manufactured goods leads directly to a reduction of output: any reduction in prices occurs only indirectly and incidentally, depending on the extent to which producers are induced to lower profit margins. A fall in demand for primary commodities, on the other hand, leads directly to a fall in prices; it leads to a restriction in output only indirectly, in so far as the decline in prices causes producers to lower their output."

Much less discussed, but equally important was the fact that this discussion took place in the context of explicit acceptance of an international gold standard, or a multilateral international system based on stability of US dollar exchange rates. Solutions were thus sought within this framework. Buffer stock schemes were devised to provide an offset to the operation of competitive prices. Import and export tariffs, or subsidies and quotas were justified for infant industries and used to adjust 
fixed exchange rates. Alternatively, multiple exchange rates were proposed for different outputs, in particular for primary and manufactured goods.

Exemplary of this approach, Diamand (1978) points out "Since the developing industrial sector will not only have a level of productivity lower than that prevailing in traditional primary production sector, it will also have lower productivity than in developed countries. This means manufacturing exports will have higher prices than prevail in international export markets. Since exchange rates are primarily determined by exports of the more productive primary sector, manufactured exports will be doubly disadvantaged as the overvaluation of the exchange rate reinforces the international divergence in domestic productivity." The result is two sectors with very different productivities co-exist: a "less dynamic primary sector which works at international prices and exports, and the protected and more dynamic industrial sector which works at prices higher than international ones and, unless it is given special industrial exchange rates for export, produces only for domestic consumption." "The first measure should thus consist in restructuring the industrial exchange rates for exports.... we would have two basic exchange rates. The nominal rate \{representing a more expensive dollar\} ... for financial transactions, industrial exports and, with the corresponding import duties (much lower than in the conventional system), also for imports. On the other hand, we would have the primary exchange rate for \{primary goods\} exports, determined by the nominal rate less export duties. This reform would bring the nominal exchange rate substantially closer to the structure of industrial costs and would improve the possibility to export manufactured goods. Another alternative or complementary procedure is to build up a de facto exchange system for exports with tax reimbursements and other fiscal stimuli." (Diamand, 1978, p. 25)

For Kaldor (1965) "When import requirements exceed the capacity to export on account of high domestic costs, ... [this is because the exchange rate which would make it possible for an under-developed country to develop export markets in manufactured products would mean a considerable under-valuation of its currency in terms or primary commodities." Kaldor reaches the same conclusion, that "there is no single rate of exchange which is capable... of securing equilibrium between domestic costs of production and the prices, or the level of costs, in foreign markets" In agreement with Diamand "There is no way out of this dilemma except by some system of dual exchange rates, or some system of combined taxes and subsidies which produce the same effect as dual exchange rates” (p. 188).

The New Development Economics thus finds itself within the framework of discussion of the "old" development economics when it calls attention to the importance of the exchange rate in supporting an existing sectoral imbalance in production, and in preventing measures to adjust it. Where the NDE departs from this traditional approach is in the identification of the causes of the imbalance.

The first difference is to substitute for the tendency to the decline in the terms of trade the tendency for domestic real wages to lag productivity growth. The framework is thus expanded beyond the structural difficulties in the agricultural sector and the behavior of commodity prices to the conditions in the labour market 
and behavior of wages relative to profitability. Instead of rising primary commodity production producing a decline in prices and a decline in export earnings, now the argument is the rising productivity failing to produce an equivalent rise in purchasing power and a decline in value added from the export of manufactured goods, with the benefits of higher productivity in manufacturing accruing to foreign owners or domestic capitalists. The other side of this relation is the sustained income inequality registered in developing countries.

The NDE seeks to encompass these factors under the umbrella of the "Dutch disease" and the form of the argument is similar, but the nature of the disease is different, and this tends to mask the fact that even if a developing economy manages to expand its manufacturing sector it may face the same difficulties that the "old" development theory suggested might be ameliorated by the expansion of manufacturing.

Finally, the negative impact of foreign direct investment in aggravating the wage productivity gap, as well as providing distortions in exchange rates. Indeed, the opening for domestic financial markets to unfettered foreign capital inflows has a more negative impact on the exchange rate than any dominance of primary exports. The implication is in favor of increased domestic financing, and limitations foreign capital inflows. The appropriate exchange rate will then be part of a policy package managing foreign capital flows.

Thus the NDE makes explicit what was always implicit in the "old" that the root problem facing developing contrived is not only in the perverse operation of the price mechanism, market distortions and the associated elasticities of production and demand for primary commodities, it is in the overall level of demand. Irrespective of the behavior of wages relative to productivity, technical progress in all sectors will be reducing the employment coefficients and creating more technological unemployment. Indeed, this was a central element of Prebisch's analysis of the impact of the terms of trade dilemma - increasing productivity in agriculture was not transformed into higher domestic wages and purchasing power, but into lower output prices and thus higher purchasing power for the workers in developed countries who bought them. It was this transfer of the fruits of productivity growth from developing to developed countries which provided the real barrier to the expansion of manufacturing because of the lack of domestic demand to support its expansion. But not only was purchasing power lost, the productivity growth produced higher levels of unemployment, or disguised unemployment in agriculture.

This is Kaldor's "second handicap" mentioned above: "whereas the benefits of technical progress in manufacturing are largely retained by the producers (in the form of higher real wages and profits), the benefits of technical progress in the primary production are largely passed on to the consumers, in the form of lower prices, leaving little benefit to the producers in the form of higher real income." (Ibid.) Kaldor adds a note at this point: "This is partly due to the prevalence of imperfect competition in manufacturing and partly to the fact that organizations of industrial workers are in a position -unlike workers in the agricultural sectors 
of under-developed countries - to ensure that industrial wages increase at least as fast as industrial productivity

In the NDE, this argument is expanded to productivity growth in all sectors creating the possibility for higher wage growth at the same time it reduces the employment requirements per unit of output. It is no longer a question of the differential behavior of different sectors. Indeed, the disease is more virulent in manufacturing than in agriculture. Thus demand sufficient to keep overall employment expanding is as important as the need to keep remuneration in step with productivity. It is no longer simply the question of the appropriate exchange rate for the manufacturing sector, but that for the mix of exports that allows for sufficient employment growth.

Already in 1977, one of the "old" development theorists Gerald Meier wrote: "The labor absorption problem is now the central problem of development. In a group of 14 LDCs ...from the late 1950s to 1970, the total of known unemployed grew an average of more than $8 \%$ a year - about three times the population growth rate. The labor force of the developing market economy countries was approximately 700 million in 1975 , but ...almost 300 million (some $40 \%$ ) were unemployed or underemployed. About $5 \%$... were openly unemployed - "persons without a job and looking for work." About another 35\%, however, were "underemployed - persons who are in employment of less than normal duration and who are seeking or would accept additional work" and" persons with a job yielding inadequate income". Not only is there already an extremely large pool of underemployed; even worse, the projected growth in the labor force portends to exacerbate the employment problem as never before. It is expected that the growth of the labor force will accelerate - to some $2.7 \%$ a year, in contrast with $2.0 \%$ a year in 1960-70. This would amount to a doubling of the labor force in LDCs in the last quarter of the century. It is striking that even a conservative estimate indicates that the LDCs will experience over 1970 - 2000 an increasing labor force equivalent to double the size of the entire labor force that was in the developed countries as recently as 1950 - some two centuries after the Industrial Revolution.”

Thus the New Developmentalism shifts us from a concern for manufacturing and the appropriate exchange rates to the overarching problem of providing employment in the face of rising productivity and income inequality. This will be just as much a question of the development of domestic financing for employment growth as it is management of the exchange rate. It will require positive measures to develop domestic financing institutions as well as measures to limit or eliminate foreign capital which is the real virus that generates the Dutch disease in developing countries.

\section{REFERENCES}

Diamand, Marcel (1978). "Towards a change in the economic paradigm through the experience of developing countries." Journal of Development Economics 5, 19-53. 
Kaldor, Nicholas. (1963) "Stabilising the terms of trade of under-developed countries". Economic Bulletin for Latin America. (Reprinted in N. Kaldor, Essays on Economic Policy - Volume Two, New York: Norton, 1964, pp.121-2.)

Kaldor, Nicholas. (1965). "Dual exchange rates and economic development". Reprint-ed in Essays on Economic Policy, Vol. 2. New York: W.W. Norton, 187-188

Lewis, Arthur. (1954). "Economic development with unlimited supplies of labour," The Manchester School, No. 22, May.

Meier, Gerald M. (1977) "Employment, trade and development: a problem in international policy analysis”, A.W. Sijthoff, Leiden, Institut Universitaire de Hautes Etudes Internationales, Geneve, 1977

Prebisch, Raúl (1959). "Commercial policy in the underdeveloped countries". American Economic Review. 49: 251-273.

Rosenstein Rodan, P.N. (1943). "Problems of industrialisation of Eastern and South-Eastern Europe." The Economic Journal 53(210/211), 202-211. 